\title{
Process Simulation of a 620 Mw-Natural Gas Combined Cycle Power Plant with Optimum Flue Gas Recirculation
}

\author{
Ahmed Badr Al Hashmi, Abdel Aziz Abdulla Mohamed, Zin Eddine Dadach* \\ Chemical \& Petroleum Engineering Department, Abu Dhabi Men's College, Higher Colleges of Technology, Abu Dhabi, UAE
}

Email: ${ }^{\star}$ zdadach@hct.ac.ae

How to cite this paper: Al Hashmi, A.B., Mohamed, A.A.A. and Dadach, Z.E. (2018) Process Simulation of a $620 \mathrm{Mw}$-Natural Gas Combined Cycle Power Plant with Optimum Flue Gas Recirculation. Open Journal of Energy Efficiency, 7, 33-52. https://doi.org/10.4236/ojee.2018.72003

Received: March 17, 2018*

Accepted: May 14, 2018

Published: May 17, 2018

Copyright $(0) 2018$ by authors and Scientific Research Publishing Inc. This work is licensed under the Creative Commons Attribution International License (CC BY 4.0).

http://creativecommons.org/licenses/by/4.0/

\begin{abstract}
The main objective of this investigation is to obtain an optimum value for the flue gas recirculation ratio in a $620 \mathrm{MW}$-Natural Gas Combined Cycle (NGCC) power plant with a $100 \%$ excess air in order to have a composition of the exhaust gas suitable for an effective absorption by amine solutions. To reach this goal, the recirculated flue gas is added to the secondary air (dilution air) used for cooling the turbine. The originality of this work is that the optimum value of a Flue Gas Recirculation (FGR) ratio of 0.42 is obtained from the change of the slope related to the effects of flue gas recirculation ratio on the molar percentage of oxygen in the exhaust gas. Compared to the NGCC power plant without flue gas recirculation, the molar percentage of carbon dioxide in the flue gas increases from $5 \%$ to $9.2 \%$ and the molar percentage of oxygen decreases from $10.9 \%$ to $3.5 \%$. Since energy efficiency is the key parameter of energy conversion systems, the impact of the flue gas recirculation on the different energy inputs and outputs and the overall efficiency of the power plant are also investigated. It is found the positive effects of the flue gas recirculation on the electricity produced by the steam turbine generator (STG) are more important than its cooling effects on the power output of the combustion turbine generator (CTG). The flue gas recirculation has no effects on the water pump of the steam cycle and the increase of energy consumed by the compressor of flue gas is compensated by the decrease of energy consumed by the compressor of fresh air. Based on the Low heating value (LHV) of the natural gas, the flue gas recirculation increases the overall efficiency of the power plant by $1.1 \%$ from $57.5 \%$ from to $58.2 \%$.
\end{abstract}

\section{Keywords}

Natural Gas Combined Cycle (NGCC), Flue Gas Recirculation, Absorption by Amine, CCS 


\section{Introduction}

Global climate change is arguably the most challenging environmental problem the world will be facing in coming decades and centuries. The main source of global warming is the electricity production that generates the largest share of greenhouse gas emissions as $67 \%$ of global electricity production comes from burning fossil fuels, mostly coal and natural gas [1]. The Carbon Capture \& Storage (CCS) is included as an integral part of all climate change mitigation strategies proposed by the Intergovernmental Panel on Climate Change (IPCC) and International Energy Agency (IEA). CCS is a good and viable option for reducing $\mathrm{CO}_{2}$ emissions because it can be implemented on a large scale. However, the high capital cost is often cited as a key barrier by the potential CCS developers and investors. According to some published data, $70 \%$ to $80 \%$ of the operating cost of a CCS plant is due to the large amount of energy needed during the capture of $\mathrm{CO}_{2}$ from power generation plants using the available technologies [2].

Gas-fired power plants with Carbon Capture and Storage (CCS) are expected to play a significant role to reduce carbon dioxide emissions from the power generation sector. Compared to coal or oil-fired CHP plants, $\mathrm{CO}_{2}$ emissions from Natural Gas Combined Cycle (NGCC) technology are about 50\% and 30\% lower, respectively [3]. Moreover, natural gas (NG) is also preferred to the other heavier fuels because the environmental problems are minimized and the total cost of a Carbon Capture and Storage (CCS) is reduced by avoiding corrosion and other technical problems due to impurities $\left(\mathrm{H}_{2} \mathrm{~S}, \mathrm{SO}_{\mathrm{x}}, \mathrm{NO}_{\mathrm{x}}, \mathrm{HCl} \ldots\right)$ in the captured $\mathrm{CO}_{2}$ [4]. On the other side, in order to keep the temperatures in the gas turbine at permissible levels, the combustor has a typical overall excess air ratio (EAR) in the range $3-3.5$. As a result, flue gas has a molar percentage of $\mathrm{CO}_{2}$ in flue gas of about $3 \%-3.5 \%$ [4]. However, for an effective $\mathrm{CO}_{2}$ capture by amine solutions, it is recommended to obtain a molar percentage of $\mathrm{CO}_{2}$ in the flue gas around $10-15$ [5]. Lower $\mathrm{CO}_{2}$ concentrations in the flue gas require a leaner solvent loading to achieve an adequate "driving force" between the solvent and the flue gas stream for high levels of $\mathrm{CO}_{2}$ capture. But leaner solvent loadings require a higher $\mathrm{CO}_{2}$ removal from the solvent, which will increase the amount of energy utilized in the stripper and the cost of the $\mathrm{CO}_{2}$ capture plant.

The corrosion and degradation of amine solutions caused by the presence of oxygen in the flue gas also cause economic, operational, and environmental problems. Literature review of the laboratory studies and pilot plant scale experiments clearly indicates that these solvents undergo, in presence of oxygen, both oxidative and thermal degradation [6]. According to Chakravarti et al. [7], oxidative degradation of amine solutions occurs when the flue gases contain a molar concentration of oxygen of about $5 \%$. As a consequence, flue gas from natural gas fired turbines will increase the operating cost of the $\mathrm{CO}_{2}$ capture unit also because they contain higher concentrations of oxygen.

High Flue Gas Recirculation (FGR) ratios are desirable because they increase the $\mathrm{CO}_{2}$ concentration and decrease the $\mathrm{O}_{2}$ concentration in the flue gas to be 
treated in the absorption unit. However, the combustion process sets a limit due to the corresponding reduction in $\mathrm{O}_{2}$ concentration. Due to the importance of the recirculation rate on the overall performance of the $\mathrm{CO}_{2}$ removal process, combustion studies are required in order to define the optimum achievable recirculation rate. The optimum value of FGR ratio will depend mainly on the properties of the combustible, the amount of excess air used and the turbine mechanical limitations.

The first part of this study is to simulate a Natural Gas Combined Cycle (NGCC) for a production of about $620 \mathrm{MW}$ of electricity using the commercial software Aspen HysysV9.0 and the Soave-Redlich-Kwong (SRK) equation of state. Secondly, in order to reduce the cost of capturing $\mathrm{CO}_{2}$ and minimize technical problems related to oxidative degradation of amine solution, optimum value of the flue gas recirculation ratio will be estimated by investigating the effects of the FGR ratio on the composition of carbon dioxide and oxygen in the flue gas. Based on the Optimum FGR ratio, the final objective of this study is to investigate the impact of flue gas recirculation on the different energy inputs and outputs of the power plant and on its overall efficiency. Based on the results of this investigation, the second part of this work is to simulate both a carbon dioxide absorption plant by amine solution followed by a carbon dioxide compression unit for a future enhanced oil recovery (EOR) project.

\section{Methodology}

\subsection{Description of a Typical Natural Gas Combined Cycle Power Plant}

As shown in Figure 1, the simplified NGCC (Natural Gas Combined Cycle) power plant is divided into seven different control volumes: Compressor $(\mathrm{K})$, Combustor (CC), Combustion Turbine Generator (CTG), Steam Turbine Generator (STG), Heat Recovery Steam Generator (HRSG), Condenser (C) and Pump (P).

Following the process flow diagram: 1) Fresh air enters the compressor. 2) It is then compressed to a higher pressure. Upon leaving the compressor, air enters

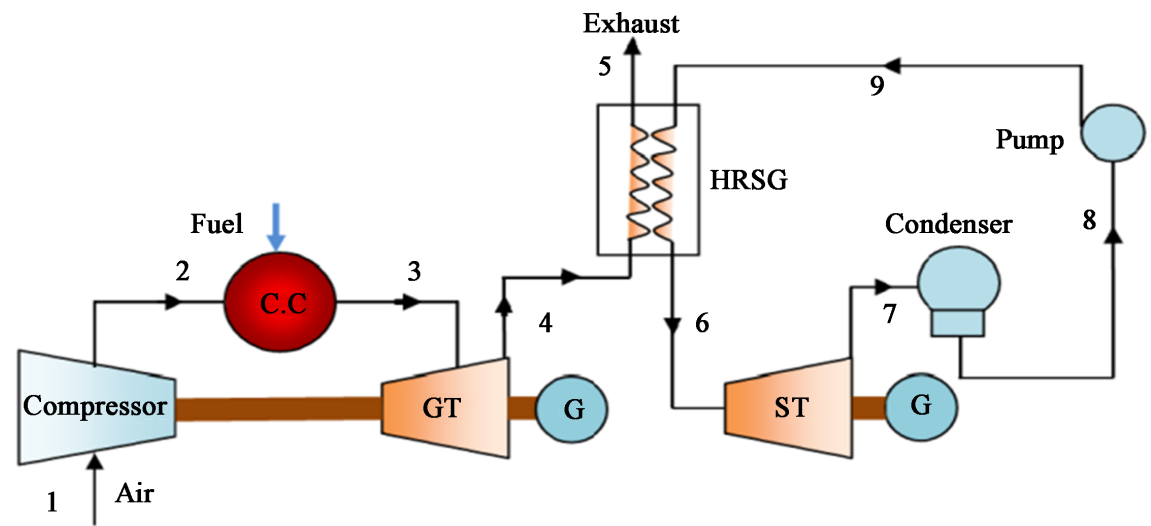

Figure 1. Schematic representation of a natural gas combined cycle [8]. 
the combustion system, where natural gas (NG) is injected and combustion occurs. The combustion process occurs essentially at constant pressure. 3) The exhaust gas leaves the combustor and enters the Combustion Turbine Generator (CTG). In the turbine section, the flue gas is expanded to produce electricity. 4) The flue gas leaves the CTG at high temperature. This first part of the power plant is called Open Cycle Gas turbine (OCGT). In the second part of the NGCC, the hot stream from the gas turbine will generate steam in a Heat Recovery Steam Generator (HRSG).The steam cycle consists of a HRSG, Steam Turbine Generator (STG), condenser, and pump to form a Rankine cycle for electricity production. Water enters the HRSG at high pressure and the resulting steam produce electricity in the steam turbine generator (STG). The saturated steam leaving the steam turbine is first condensed and then its pressure increased before returning to the HRSG. The de-aerator of the steam cycle is not included in this investigation.

\subsection{Preliminary Calculations}

The objective of the preliminary calculations is to determine 1) the amount of natural gas, 2) excess air and 3) the theoretical flue gas recirculation ratio in a natural gas combined cycle (NGCC) power plant in order to produce about 600 MW electricity.

\subsubsection{Mass Flowrate of the Natural Gas}

Fresh air at ambient temperature is first compressed to $3 \mathrm{MPa}$ then mixed with natural gas (NG) in the combustor of the gas turbine. It is assumed that combustion is complete and all the carbons in NG convert to $\mathrm{CO}_{2}$. The average composition of the available natural gas is presented in Table 1.

For the given mass composition, the average Low Heat Value (LHV) of the natural gas is equal to $46.7 \mathrm{MJ} / \mathrm{kg}$ (Aspen Hysys). Based on the LHV, the overall efficiency of NGCC is around 58\% [9]. For a power plant producing $600 \mathrm{MW}$ with an overall efficiency of $58 \%$, the needed flow rate of the hydrocarbons of the available natural gas is $22.74 \mathrm{~kg} / \mathrm{s}$. The corresponding mass flow rate of the natural gas stream is equal to $23.81 \mathrm{~kg} / \mathrm{s}$.

Table 1. Natural gas composition.

\begin{tabular}{cccc}
\hline Fuel Composition & Mole (\%) & Mass (\%) & MW \\
\hline $\mathrm{CO}_{2}$ & 1.0 & 2.6 & 44 \\
$\mathrm{CH}_{4}$ & 93.0 & 87.6 & 16 \\
$\mathrm{C}_{2} \mathrm{H}_{6}$ & 3.0 & 5.3 & 30 \\
$\mathrm{C}_{3} \mathrm{H}_{8}$ & 1.0 & 2.6 & 44 \\
$\mathrm{O}_{2}$ & 2.0 & 1.9 & 16 \\
Total & 100 & 100 & 16.98 \\
\hline
\end{tabular}




\subsubsection{Stoichiometric Air}

The stoichiometric combustion is a theoretical point in which the optimum amount of oxygen and fuel mix generates the most heat possible and maximum combustion efficiency is achieved. Natural gas mixes with compressed air in the combustor and it is assumed that combustion is complete and all the carbons convert to $\mathrm{CO}_{2}$. The following reactions were used to estimate the theoretical amount of air needed for combustion only:

$$
\begin{gathered}
\mathrm{CH}_{4}+\left(2 \mathrm{O}_{2}+7.52 \mathrm{~N}_{2}\right) \rightarrow \mathrm{CO}_{2}+2 \mathrm{H}_{2} \mathrm{O}+7.52 \mathrm{~N}_{2} \\
\mathrm{C}_{2} \mathrm{H}_{6}+\left(3.5 \mathrm{O}_{2}+13.17 \mathrm{~N}_{2}\right) \rightarrow 2 \mathrm{CO}_{2}+3 \mathrm{H}_{2} \mathrm{O}+13.17 \mathrm{~N}_{2} \\
\mathrm{C}_{3} \mathrm{H}_{8}+\left(5 \mathrm{O}_{2}+18.81 \mathrm{~N}_{2}\right) \rightarrow 3 \mathrm{CO}_{2}+4 \mathrm{H}_{2} \mathrm{O}+18.81 \mathrm{~N}_{2}
\end{gathered}
$$

The AFR (Air Fuel Ratio) was calculated from the mass balance of the atoms of Carbon, Oxygen, Hydrogen and Nitrogen in Equations (1) to (3). Solving the four atomic material balances, the molar stoichiometric AFR (Air Fuel Ratio) is 9.90 and the corresponding mass AFR is 16.91 . As a result, $384.53 \mathrm{~kg} / \mathrm{s}$. of stoichiometric air need to be added to $23.81 \mathrm{~kg} / \mathrm{s}$. of natural gas stream for complete combustion. However, for a turbine using natural gas, $10 \%$ of excess air is normally added to the stoichiometric air for combustion [10]. Excess Air (EA) is expressed as a percentage increase over the stoichiometric requirement and is defined as;

$$
\mathrm{EA}=\frac{\text { Actual AFR }- \text { Stoichiometric AFR }}{\text { Stoichiometric AFR }} \times 100 \%
$$

It is sometimes convenient to use the Excess Air Ratio (EAR) defined as:

$$
\mathrm{EAR}=\frac{\text { Actual AFR }}{\text { Stoichiometric AFR }}
$$

Using Equation (4) and for $10 \%$ excess air, the optimum value of the molar and the mass AFR are 10.89 and 18.60 respectively. The corresponding optimum mass flowrate of primary air for combustion only is $422.98 \mathrm{~kg} / \mathrm{s}$.

\subsubsection{Optimum Values of Flue Gas Recirculation (FGR) Ratio}

As shown in Figure 2, primary air of the gas turbine is the main combustion air. This air is mixed with fuel, and then combusted. Intermediate air is the air injected into the combustion zone. This air completes the reaction processes and

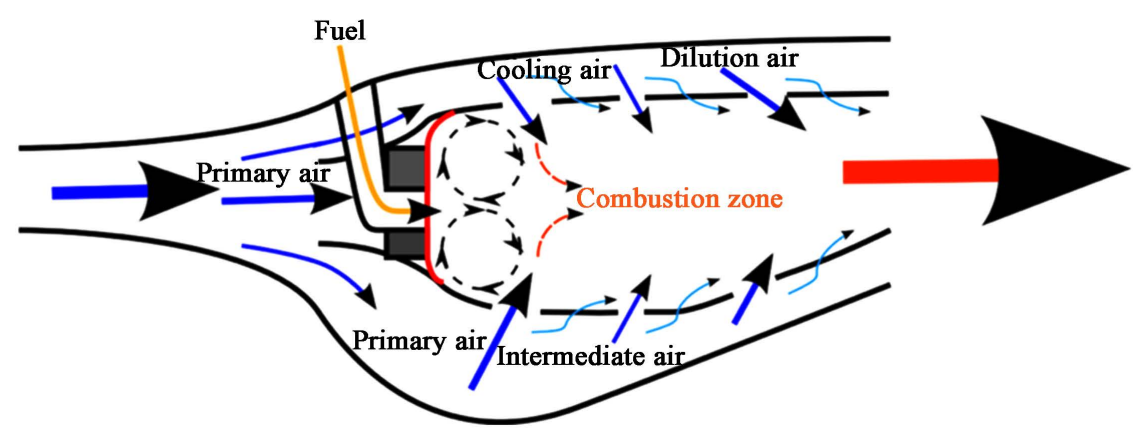

Figure 2. Different air flow paths in gas turbine [11]. 
cools down the combustion gases. Dilution air is injected at the end of the combustion chamber to help cool the air to before it reaches the turbine stages. In this study, it is assumed that the primary air (with excess air for combustion) includes both the primary air and intermediate air and the secondary air is the dilution air. The recirculated flue gas is added to the secondary air to be used for cooling the turbine.

A maximum value of the flue recirculation ratio is needed in order to respectively maximize the $\mathrm{CO}_{2}$ concentration and minimize the $\mathrm{O}_{2}$ concentration in the flue gas to be treated in the absorption unit. However, the stability of the flame and the efficiency of the combustion process are also key parameters to consider in order to fix the minimum amount of oxygen needed. For energy-efficient combustion process, the flame is supposed to operate within the stability limits yet with smallest possible fuel consumption. Air entrainment is usually used to provide partially premixed flames. Experiments conducted in a $65 \mathrm{~kW}$ combustor operating in a pre-mixed flame mode, indicates that the blow out limit (the point at which a premixed fuel and air mixture is unable to self-sustain) occurs with an oxygen concentration below 13 - 14 vol\% [12]. According to ElKady and co-workers, a higher minimum oxygen concentration of $16-17$ vol\% is necessary for good combustion efficiency with acceptable low levels of CO [13]. It should also be noted that unburned methane is a vastly more potent greenhouse gas than carbon dioxide itself, and so gas discharged upstream of its end use adds significantly to the overall climate change impact of the fuel. In this study, Aspen HysysV9.0 and the Soave-Redlich Kwong (SRK) equation of state are first utilized in order to estimate the maximum value of FGR ratio for an excess air varying from $100 \%$ to $600 \%$. Based on the preliminary calculations, Table 2 shows the corresponding values of the optimum FGR for EA (Excess Air) changing from $100 \%$ to $600 \%$.

For the selected case study of an excess air of $100 \%$, the corresponding mass AFR is equal to 33.82. Therefore, the needed amount of air for combustion and cooling is equal to $768.9 \mathrm{~kg} / \mathrm{s}$. $(422.98 \mathrm{~kg} / \mathrm{s}$ are used as primary air for combustion and $346.09 \mathrm{~kg} / \mathrm{s}$ are used as secondary air for cooling.) This value corresponds to an optimum value of FGR ratio of 0.44 .The relationship between the optimum FGR ratio and the excess air (EA) values is shown in Figure 3.

Table 2. Optimum values of Flue gas Recirculation (FGR) Ratio for different values of EA.

\begin{tabular}{cccccc}
\hline EA (\%) & Mass AFR & $\begin{array}{c}\text { Total air } \\
(\mathrm{kg} / \mathrm{s})\end{array}$ & $\begin{array}{c}(\text { Air }+\mathrm{NG}) \\
(\mathrm{kg} / \mathrm{s})\end{array}$ & $\begin{array}{c}\text { Optimum Flue } \\
\text { gas recycled }(\mathrm{kg} / \mathrm{s})\end{array}$ & $\begin{array}{c}\text { Optimum } \\
\text { FGR ratio }\end{array}$ \\
\hline $\mathbf{1 0 0}$ & $\mathbf{3 3 . 8 2}$ & $\mathbf{7 6 8 . 9}$ & $\mathbf{7 9 2 . 8 9}$ & $\mathbf{3 4 6 . 0 9}$ & $\mathbf{0 . 4 4}$ \\
200 & 50.72 & 1153.37 & 1177.18 & 730.39 & 0.62 \\
300 & 67.63 & 1537.96 & 1561.77 & 1114.98 & 0.71 \\
400 & 84.54 & 1922.45 & 1946.26 & 1499.47 & 0.77 \\
500 & 101.45 & 2306.94 & 2330.75 & 1883.96 & 0.81 \\
600 & 118.36 & 2691.43 & 2675.67 & 2225.44 & 0.83 \\
\hline
\end{tabular}




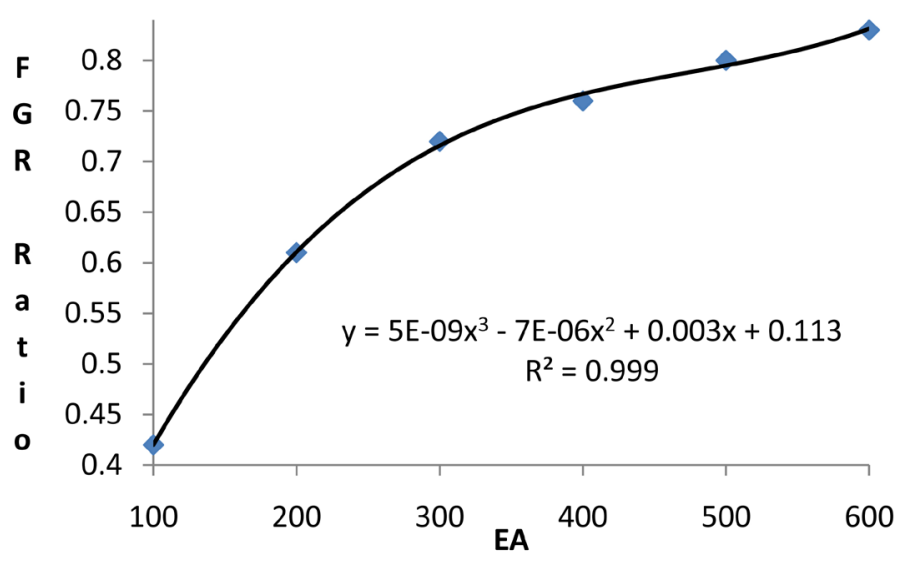

Figure 3. Effects of excess air (EA) on the optimum value of FGR ratio.

\subsection{Simulation of the Effects of FGR Ratio on the Composition of Flue Gas}

For an effective absorption by amine solutions, the molar percentage of $\mathrm{CO}_{2}$ in the flue gas should be higher than $10 \%$. In order to reduce technical problems linked to oxidative degradation of amine in the $\mathrm{CO}_{2}$ capture plant, the percentage of $\mathrm{O}_{2}$ in the flue gas should also be lower than 5\%.The positive effects of Flue Gas Recirculation (FGR) on the composition the flue gas have also been investigated [2] [5] [12] [14] Akram et al. [5] studied the effects of recirculating part of flue gas in a $100 \mathrm{KW}$ (plus $150 \mathrm{KW}$ hot water) CHP gas turbine TurbecT100. Their preliminary results indicate that a recirculation ratio of $0.45 \mathrm{in}-$ creased the molar percentage of $\mathrm{CO}_{2}$ from $1.5 \%$ to $3.0 \%$ and the molar percentage of $\mathrm{O}_{2}$ decreased from $18.2 \%$ to $16.0 \%$. Their results show also that recycling part of the flue gas decreases NOx emissions by decreasing the flame temperature. Using a natural gas-fired power plant of $700 \mathrm{MW}$, the results presented by Bolland and Saether [2] show that, using a recirculation ratio of 0.4, the molar percentage of $\mathrm{CO}_{2}$ increased from $3.3 \%$ to $5.5 \%$ and the molar percentage of $\mathrm{O}_{2}$ decreased from $13.8 \%$ to $9.8 \%$. To maintain high cycle efficiency, flue gas was cooled before reinjection in the combustor. Abu Zahra [14] used Aspen plus and the Peng-Robinson equation of state, to simulate the effect of flue gas recirculation in an IGCC power plant using a low-pressure gasifier. With all the other parameters of the gas turbine constant, the results indicated that the concentration of $\mathrm{CO}_{2}$ increased from 7.3 (\% mol.) to 14.0 (\% mol.) with the increase of the flue gas recirculation ratio from $0 \%$ to $45 \%$. Moreover, the concentration of $\mathrm{O}_{2}$ decreased from 14.2 (\% mol.) to 8.0 (\% mol.) with the same increase of flue gas recirculation. This part of this investigation is to simulate the impact of flue gas recirculation ratio on its composition for a gas turbine with an excess air (EA) of $100 \%$. First, the simulation results of the molar percentage of $\mathrm{CO}_{2}$ in the flue gas are shown in Figure 4.

As shown in Figure 4, The Flue gas recirculation increases the molar percentage of carbon dioxide in the flue gas entering the absorption unit from 5.8 (FGR $=0.1)$ to $11.0(\mathrm{FGR}=0.53)$. However, from a value of FGR ratio equal to 0.5 , the 


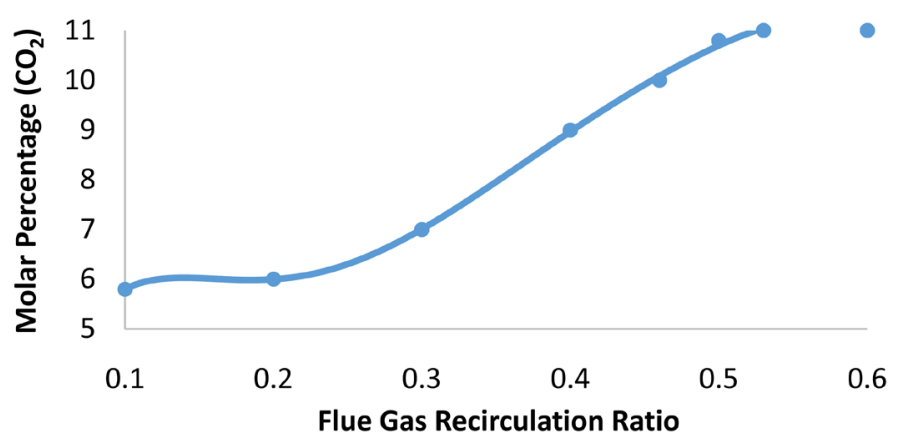

Figure 4. Effects of FGRRatio on the content of $\mathrm{CO}_{2}$ in the flue gas.

molar percentage of carbon dioxide stays constant. This observation could indicate that there is not enough oxygen for the combustion process and carbon monoxide is being formed instead of carbon dioxide. This could also be explained by the fact that the simulated mass flow rate of fresh air $(361.1 \mathrm{~kg} / \mathrm{s})$ is lower than the minimum needed stoichiometric value of $384.53 \mathrm{~kg} / \mathrm{s}$. The optimum value of the flue gas recirculation ratio should therefore be lower than 0.50 . Secondly, the effects of the flue gas recirculation (FGR) ratio on the concentration of $\mathrm{O}_{2}$ of the flue gas entering the absorption unit are shown in Figure 5.

As expected, the flue gas recirculation decreases the molar percentage of oxygen in the stream entering the absorption unit from $9.4(\mathrm{FGR}=0.1)$ to 0.0 (FGR $=0.53$ ). However, the slope of curve for the values of FGR ratio above 0.42 is larger than the slope of the part of the curve for value of FGR ratio lower than 0.42 . This value is selected in this study as the optimum FGR ratio. The corresponding excess air in the primary air is $17 \%$ and the molar composition of oxygen in the mix natural gas-primary air is 0.19 . This molar composition of oxygen in the gas -air mixture is higher than the value of 0.17 given in the literature as the minimum concentration for the stability of the flame [13]. In practice, good efficiency of the combustion could be obtained by controlling oxygen and carbon monoxide content in the exhaust gas. For example, the measured CO concentration can be used for combustion control by two methods: controlling $\mathrm{O}_{2}$ when the $\mathrm{O}_{2}$ concentration exceeds a prescribed value and overriding to $\mathrm{CO}$ control when the $\mathrm{O}_{2}$ concentration falls below the value, or giving a $\mathrm{CO}$ concentration bias (compensation) to the $\mathrm{O}_{2}$ concentration (Figure 6).

\subsection{Process Description of the Simulated NGCC Power Plant}

As shown in Figure 7, a $600 \mathrm{MW}$-natural gas combined cycle (NGCC) with a flue gas recirculation ratio of 0.42 is simulated in this study. $23.81 \mathrm{~kg} / \mathrm{s}$ of natural gas $\left(\mathrm{CH}_{4}=93 \% \mathrm{~mol}\right)$ is supposed to be available in a battery limit of the plant at $3.1 \mathrm{MPa}$ and $25^{\circ} \mathrm{C}$ and $449.2 \mathrm{~kg} / \mathrm{s}$ of fresh air at design condition is compressed up to $3.1 \mathrm{MPa}$ in a three stages compressor with intercooling. NG mixes with primary air in the combustor and it is assumed that combustion is complete and all the carbons in NG convert to $\mathrm{CO}_{2}$. The temperature of the combustion gases is $2100^{\circ} \mathrm{C}$. Secondary air is mixed with recirculated flue gas to cool the combustion 


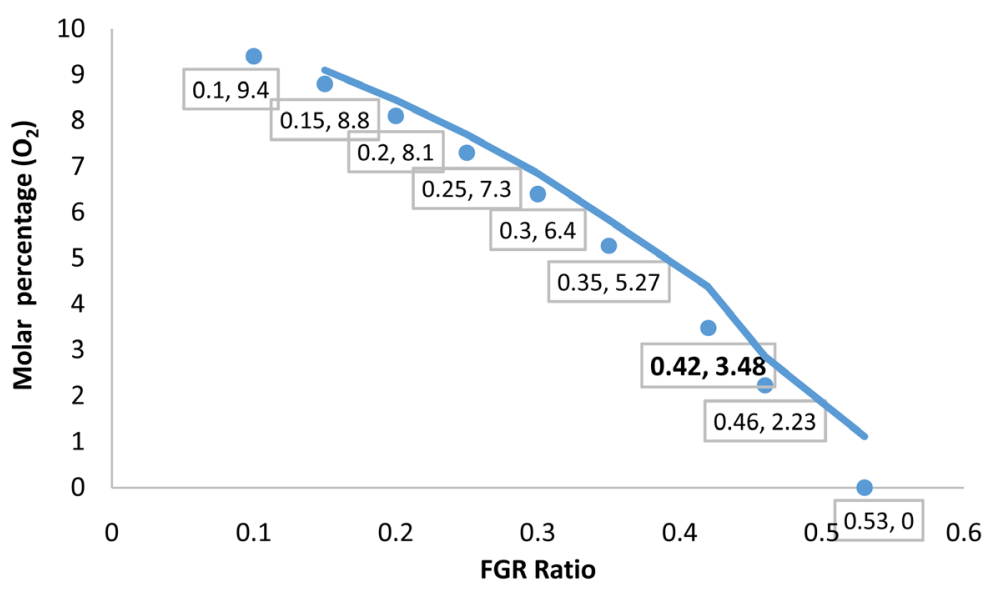

Figure 5. Effects of FGR ratio on the content of $\mathrm{O}_{2}$ in the flue gas.

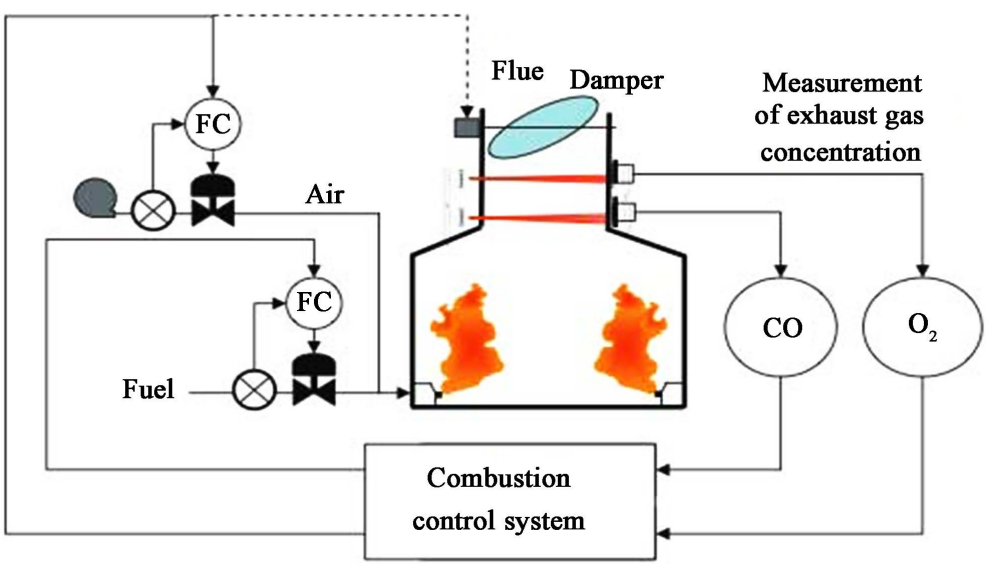

Figure 6. $\mathrm{CO}$ and $\mathrm{O}_{2}$ control system for combustion [15].

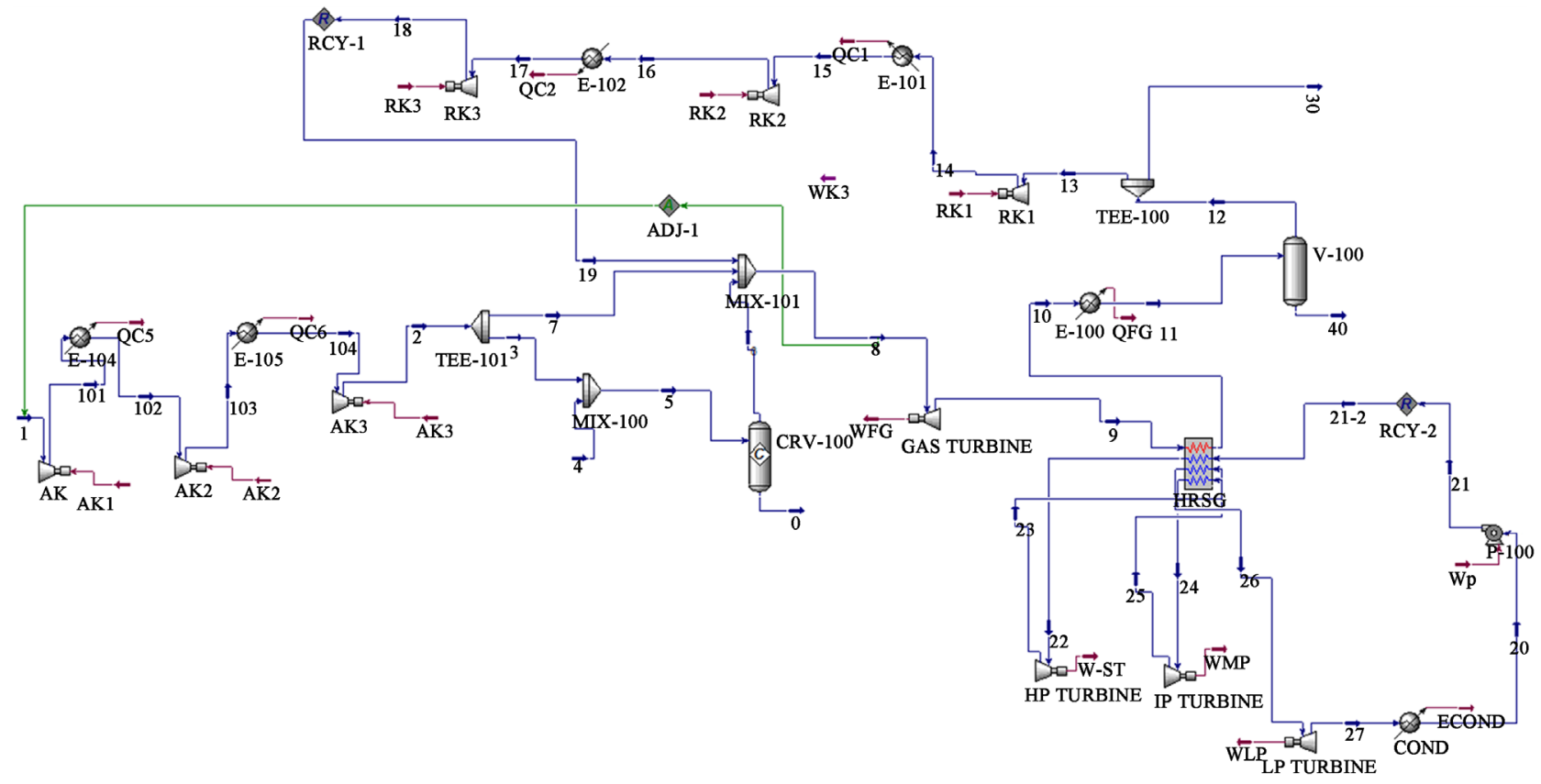

Figure 7. Simulated Natural Gas Combined Cycle (NGCC) power plant process flow sheet. 
gases until $1300^{\circ} \mathrm{C}$ before entering the turbine. The exhaust gases leave the gas turbine at atmospheric pressure and $618^{\circ} \mathrm{C}$. The flue gas enters to HRSG in order to produce $55 \mathrm{~kg} / \mathrm{s}$ of steam at three levels of pressure: high pressure (HP) steam $\left(173 \mathrm{Bars}, 600^{\circ} \mathrm{C}\right)$, an intermediate pressure (IP) steam $\left(65\right.$ bars, $\left.565^{\circ} \mathrm{C}\right)$, and a low pressure (LP) steam $\left(2\right.$ bars, $\left.350^{\circ} \mathrm{C}\right)$ with double reheat. The medium pressure steam (IP) is heated from $438^{\circ} \mathrm{C}$ to $565^{\circ} \mathrm{C}$ and the low pressure steam (LP) is heated from $206^{\circ} \mathrm{C}$ to $350^{\circ} \mathrm{C}$. After leaving the Heat Recovery Steam Generator (HRSG), the flue gas is cooled from $67^{\circ} \mathrm{C}$ to $40^{\circ} \mathrm{C}$ in order to remove water in the separator $\mathrm{V}-100$ and $42 \%$ of the flue gas is recycled. The pressure of the recycled gas will increase from $110 \mathrm{kPa}$ to $3.1 \mathrm{MPa}$ using three stages compressor with intercooling at $40^{\circ} \mathrm{C}$ and mixed with secondary ambient air.

\subsection{Simulation of the Effects of FGR Ratio on the Energies Streams of the Power Plant}

The impact of the recirculation of flue gas on the power input or output of the different equipment of the power plant are investigated. The objective is to compare the performance of each equipment of the plant with flue gas recirculation ratio of 0.42 to its performance without flue gas recirculation.

\subsubsection{Compressors}

In this study, fresh air at $15^{\circ} \mathrm{C}$ (Design conditions) is compressed up to $3.1 \mathrm{MPa}$ in three stages-compressor with intercooling at $40^{\circ} \mathrm{C}$. The pressure of the recycled gas is also increasing from $110 \mathrm{kPa}$ to $3.1 \mathrm{MPa}$ using three stages compressor with intercooling at $40^{\circ} \mathrm{C}$. An adiabatic efficiency of $85 \%$ is selected for both compressors [16]. The effects of the flue gas recirculation ratio on the energy consumption of the compressors of ambient air and flue gas are represented in Figure 8.

As expected, the flue gas recirculation ratio increases the energy needed for the compression of the recycled flue gas and decreases the energy consumption of the compressor of ambient air. Because both compressors work under same operating conditions and the main component of flue gas and atmospheric air is nitrogen, the two slopes have similar values.

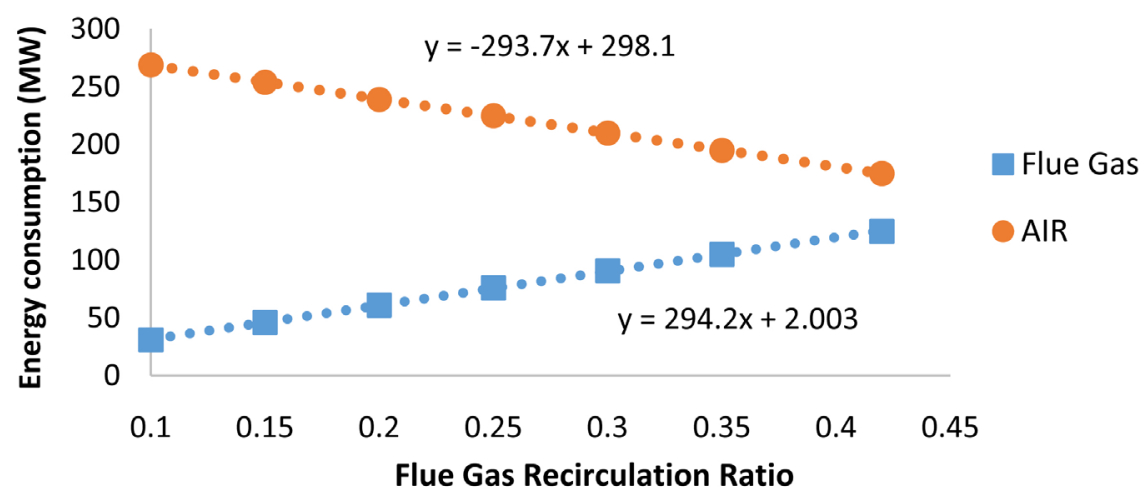

Figure 8. Effects of FGR ratio on energy consumption of compressors. 


\subsubsection{Heat Recovery Steam Generator (HRSG)}

Currently many of the steam turbines in Combined Cycle plants operate at high pressure (HP) circuit. To absorb more heat two additional evaporators are used. One operating at intermediate pressure (IP) circuit. The second at lower pressure (LP) circuit. This together with economizers and superheaters in these pressure levels enable absorbing more heat. According to the simulation outputs, the temperatures of the exhaust gas entering and leaving the heat recovery steam generator (HRSG) are respectively $618^{\circ} \mathrm{C}$ and $67^{\circ} \mathrm{C}$. The steam cycle contains a high pressure (HP) steam ( 173 bars, $600^{\circ} \mathrm{C}$ ), an intermediate pressure (IP) steam (65 bars, $565^{\circ} \mathrm{C}$ ), and a low pressure (LP) steam $\left(2\right.$ bars, $350^{\circ} \mathrm{C}$ ) with double reheat. The medium pressure steam (IP) is heated from $438^{\circ} \mathrm{C}$ to $565^{\circ} \mathrm{C}$ and the low pressure steam (LP) is heated from $206^{\circ} \mathrm{C}$ to $350^{\circ} \mathrm{C}$. The heat recovery steam generator (HRSG) was simulated without heat loss and the effects of flue gas recirculation on the heat available to produce steam are shown in Figure 9.

According to the simulation results, flue gas recirculation has positive effects on the amount of heat available in the HRSG. For the optimum value of 0.42 , the heat available in the heat recovery steam generator is $3.1 \%$ higher than heat available without flue gas recirculation. For the same temperature difference and the same mass flow rate, the positive effects of flue gas recirculation could be explained by the fact that flue gas has a specific mass heat capacity $\left(1.124 \mathrm{~kJ} / \mathrm{kg} \cdot{ }^{\circ} \mathrm{C}\right)$ higher than the specific mass heat capacity of air $\left(1.01 \mathrm{~kJ} / \mathrm{kg} \cdot{ }^{\circ} \mathrm{C}\right)$.

\subsubsection{Steam Turbine \& Pump}

The steam cycle contains High Pressure, Intermediate Pressure and Low pressure stages with two reheats. The adiabatic efficiency of the turbine, generator, and condensate pump are selected as $75 \%, 94 \%, 65 \%$ respectively [17]. The effects of the flue gas recirculation on the production of electricity by the steam turbine and the energy consumed by the pump are shown in Figure 10.

In concordance with Figure 9, Figure 10 indicates that flue gas recirculation has positive effects on the energy produced by the steam turbine. On the other

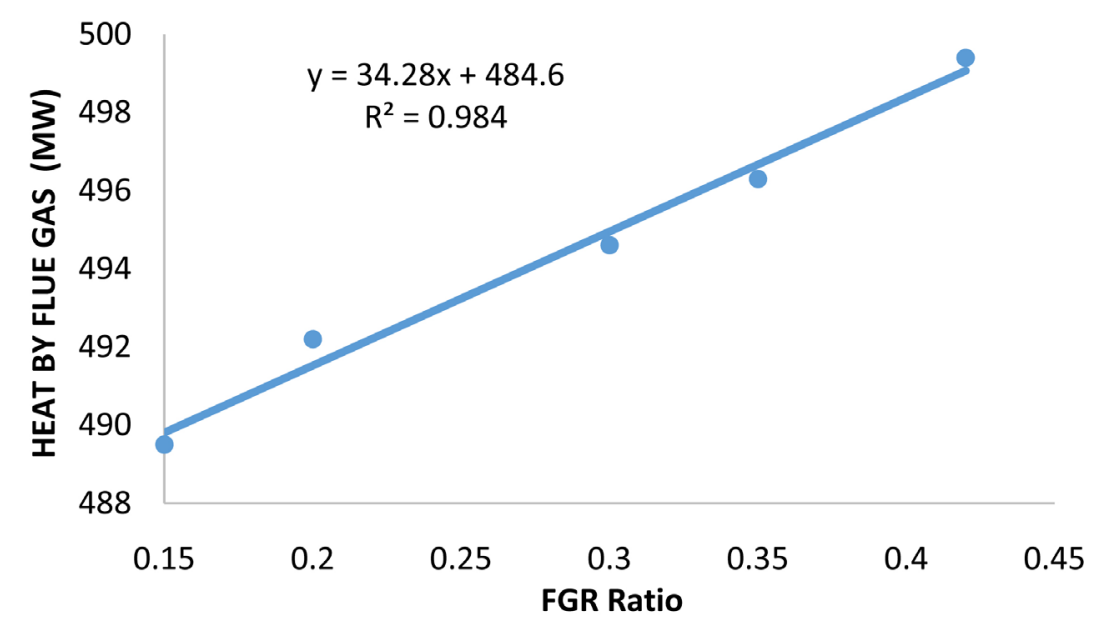

Figure 9. Effects of FGR ratio on the heat available in the HRSG. 


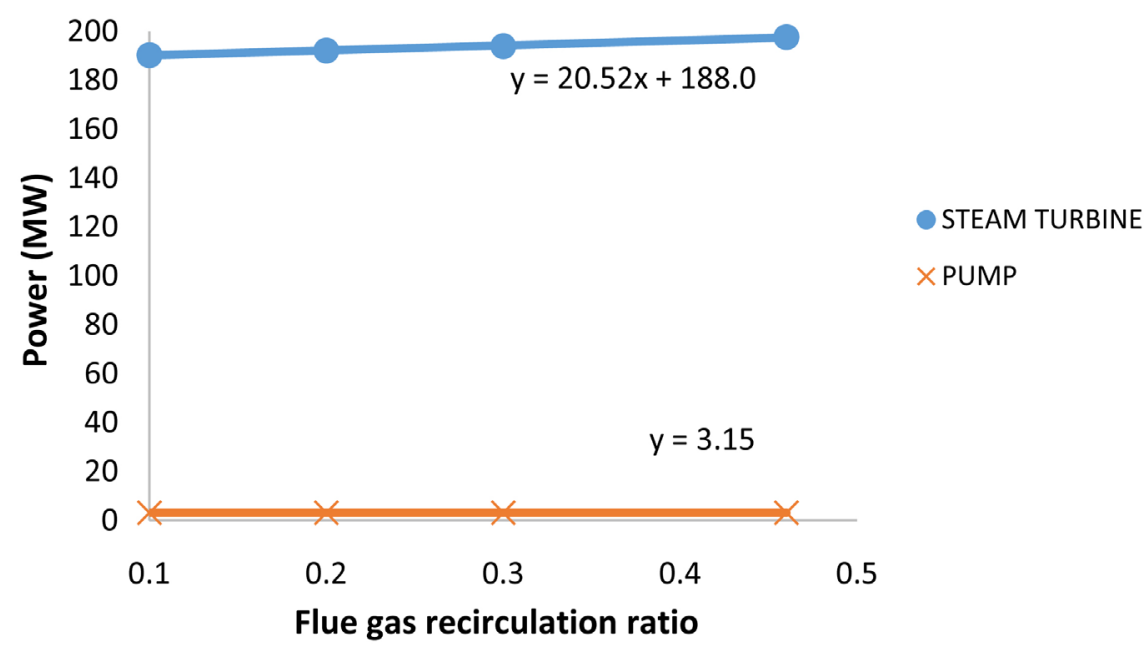

Figure 10. Effects of FGR ratio on energy of the steam cycle.

hand, it has no effects on the energy consumption of the water pump of the steam cycle. Based on simulation results, for a value of FGR of 0.42 , the steam cycle produce $4.2 \%$ more power than the steam power plant with no flue gas recirculation.

\subsubsection{Gas Turbine}

The net output of gas turbine increases with the temperature of the exhaust gas but it is limited by the metallurgical limitation for the gas turbine being utilized. The effects of Flue Gas Recirculation (FGR) ratio on the temperature of the exhaust gas leaving the combustor are therefore investigated and the simulation results are shown in Figure 11.

Figure 11 shows that the flue gas recirculation decreases linearly the temperature of the flue gas entering the gas turbine. However, recirculated flue gas has a temperature $\left(215^{\circ} \mathrm{C}\right)$ higher than the temperature of fresh air $\left(190^{\circ} \mathrm{C}\right)$. This cooling effect could also be explained by the fact that flue gas absorb more heat because its specific mass heat capacity $\left(1.124 \mathrm{~kJ} / \mathrm{kg} .{ }^{\circ} \mathrm{C}\right)$ is $11.3 \%$ higher than the specific mass heat capacity of fresh air $\left(1.01 \mathrm{~kJ} / \mathrm{kg} \cdot{ }^{\circ} \mathrm{C}\right)$. In a gas turbine, the blades have a metallurgical limitation and the temperatures could vary from $800^{\circ} \mathrm{C}$ to $1700^{\circ} \mathrm{C}$ depending on their materials and whether or not they have cooling systems [10]. According to Figure 12, The NGCC type is located between the $\mathrm{D}$ and $\mathrm{F}$ types with a flue gas temperature around $1300^{\circ} \mathrm{C}$.

Based on the information in Figure 12, the temperature $1300^{\circ} \mathrm{C}$ is therefore used in this study as the metallurgical limitation of the turbine. The effects of flue gas recirculation on the power generated by the gas turbine are shown in Figure 13.

In concordance with Figure 11, the FGR ratio decreased the power produced by the gas turbine. However, the relationship has two different slopes. At values of FGR ratio lower than 0.25 , the effects of the recirculation of flue gas on the power output of the gas turbine are negligible. For values of FGR ratio higher than 0.25 , the negative effects of the recirculation of the flue gas are more visible. 


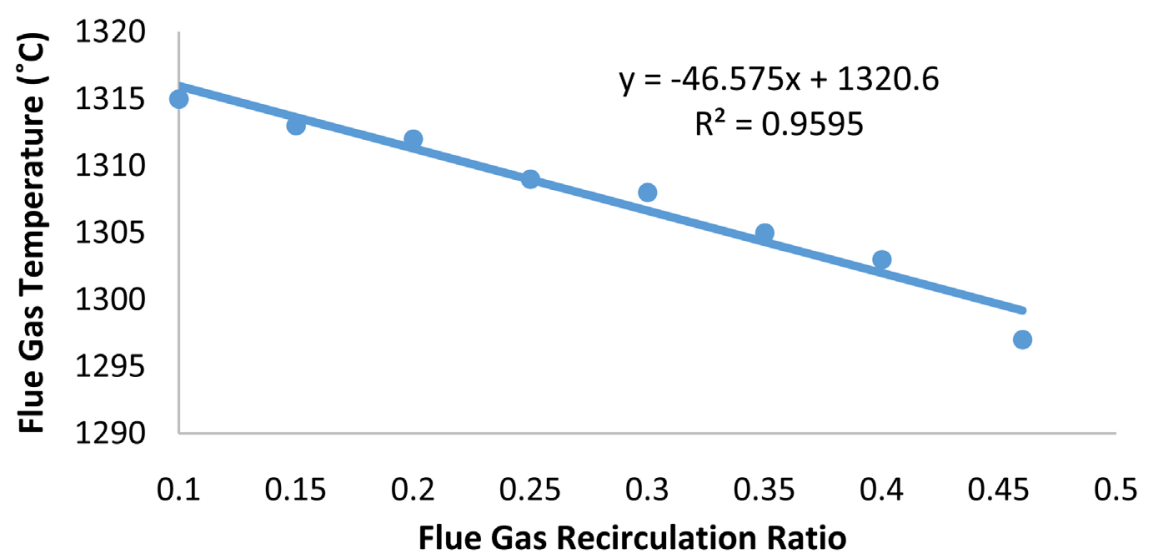

Figure 11. Effects of FGR ratio on the temperature of flue gas.

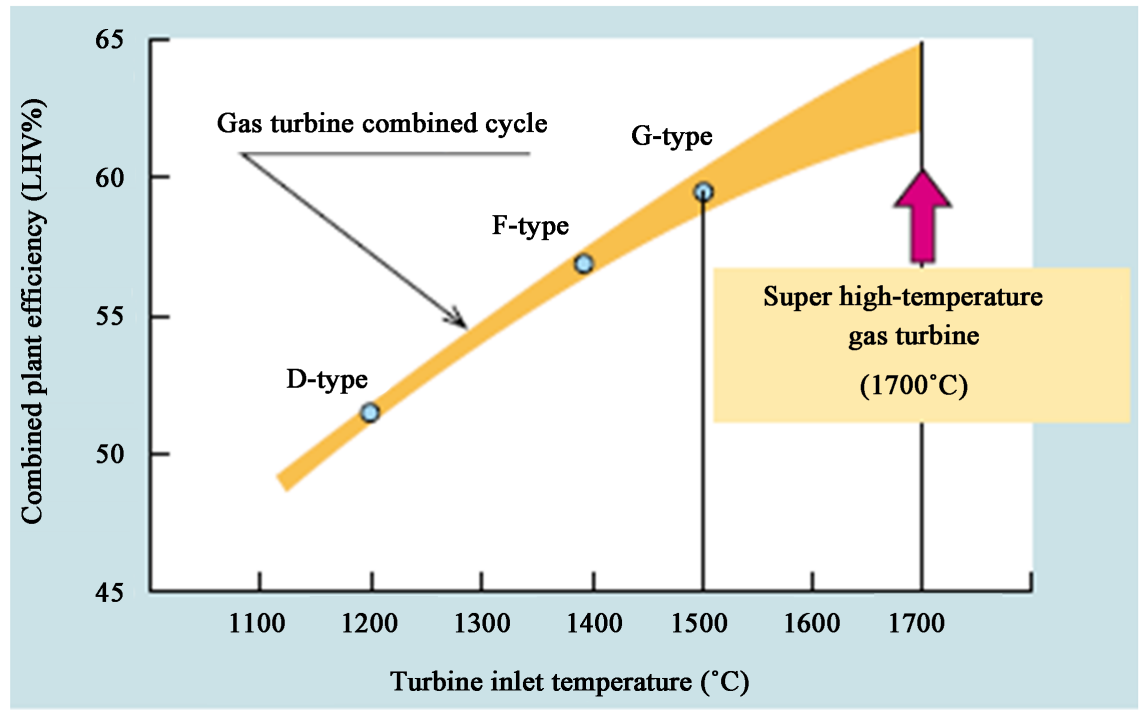

Figure 12. Turbine inlet temperature and combined plant efficiency [16].

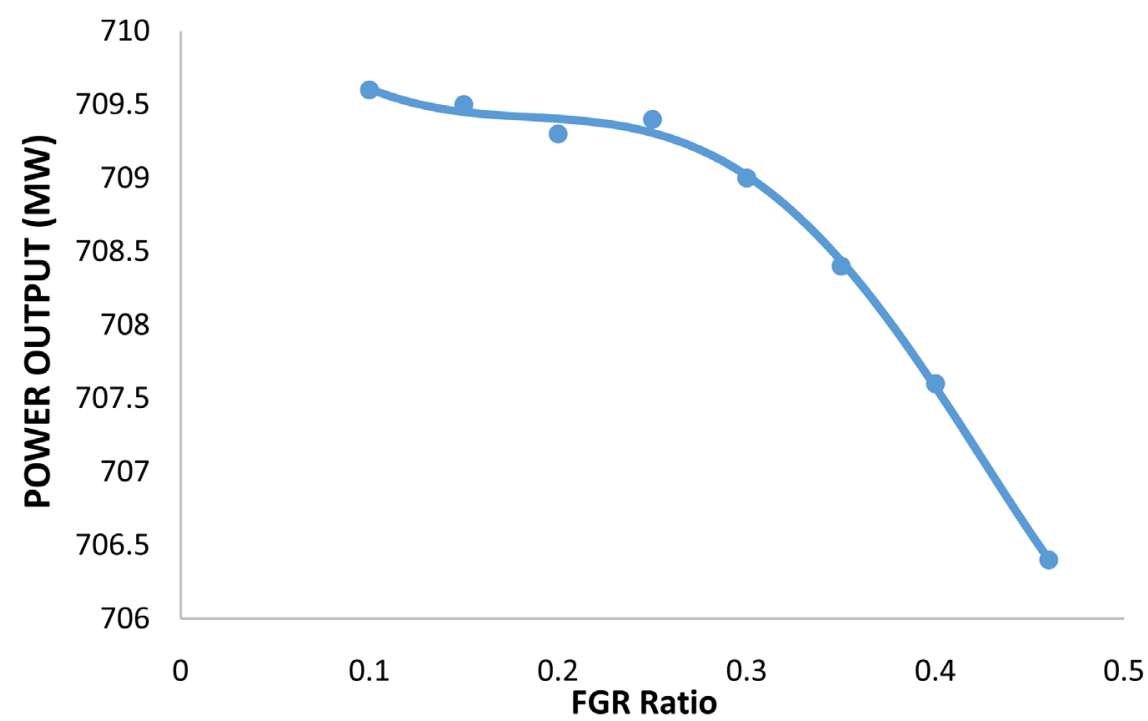

Figure 13. Effects of FGR ratio on the power generated by the gas Turbine. 


\subsection{Simulation of the Effects of FGR Ratio on the Overall Efficiency of the Power Plant}

Natural Gas Combined Cycle (NGCC) power generation is an energy conversion system of generating electric power that combines gas turbine power generation (CTG) with steam turbine power generation (STG). The thermodynamic power cycles can be categorized as gas cycles and steam cycles. Gas turbines operate using the principles of the Brayton cycle. The isentropic efficiency $\left(\eta_{i s o}\right)$ of the Brayton cycle can be expressed in terms of the temperatures and pressures entering $\left(P_{1} \& T_{1}\right)$ and leaving $\left(P_{2}, T_{2}\right)$ the compressor:

$$
\eta_{i s o}=1-\frac{T_{1}}{T_{2}}=1-\left(\frac{P_{1}}{P_{2}}\right)^{\frac{k-1}{k}}
$$

where $k$ is the specific heat ratio. Based on Equation (6), increasing the temperature of the stream leaving the compressor or increasing the pressure ratio will enhance the efficiency of the gas turbine. In this investigation, fresh air enters the compressor at design conditions of $15^{\circ} \mathrm{C}$ and the temperature of the exhaust gas is limited to $1300^{\circ} \mathrm{C}$. Based on these operating conditions, the isentropic efficiency of the gas turbine is 0.82 . This value was selected as the adiabatic efficiency of the gas turbine for the simulation of the natural gas combined cycle. The corresponding power output of the gas turbine is 708.5 MW. The compressors of fresh air and recirculation of flue gas consume respectively 174.21 MW and 125.89 MW. The net output of the gas turbine is equal to 408.4 MW.

The overall efficiency of the gas turbine could be estimated by the following equation:

$$
\eta=\frac{W_{\text {net output }}}{m_{N G} \times \text { LHV }}
$$

where $W_{\text {net output }}$ is the difference between the energy produced and the energy consumed by the different equipment of the combustion turbine generator (CTG), $m_{N G}$ is the mass flowrate of natural gas and LHV is the low heating value of natural gas. Using the Low heating value (LHV) and the mass flow rate of the natural gas (46.7 MJ/kg and $23.81 \mathrm{~kg} / \mathrm{s})$, the efficiency of the gas turbine is equal to $36.1 \%$. This value corresponds to the efficiency of the Open Cycle Gas Turbine (OCGT). The hot stream (exhaust gas) with a temperature of $617^{\circ} \mathrm{C}$ will be used to produce more electricity by generating steam in the Heat Recovery Steam Generator (HRSG). Steam turbine in a combined cycle powerplant operates using the principles of the Rankine cycle. Like the Brayton cycle, the ideal Rankine cycle operates on four internally reversible processes. The theoretical maximum efficiency of a Rankine cycle is the Carnot efficiency given in Equation (8).

$$
\eta_{\text {Carnot }}=1-\frac{T_{\text {Cold }}}{T_{\text {Hot }}}
$$

In this investigation, the highest temperature is the temperature of the steam 
entering the $\mathrm{HP}$ turbine at $585^{\circ} \mathrm{C}$ and the cold temperature is the temperature of water leaving the condenser at $30^{\circ} \mathrm{C}$. Based on these data, the maximum efficiency of the steam cycle is $64.7 \%$. The thermal efficiency of a Rankine cycle is lower than that of a Carnot cycle operating between the same temperature levels. This is primarily because of the fact that the energy transfer as heat in the boiler does not take place at constant temperature in the Rankine cycle. The purpose of a reheating cycle is to remove the moisture carried by the steam at the final stages of the expansion process and improves the efficiency of the cycle, because more of the heat flow into the cycle occurs at higher temperature.

Based on Figure 14, the thermal efficiency of the Rankine cycle with reheat is given by Equation (9):

$$
\eta=\frac{\left(h_{1}-h_{2}\right)+\left(h_{3}-h_{4}\right)+\left(h_{6}-h_{5}\right)}{\left(h_{1}-h_{6}\right)+\left(h_{3}-h_{2}\right)}=\frac{W_{\text {net-out }}}{Q_{\text {in }}}
$$

The power produced by the three turbines is equal to $32.74 \mathrm{MW}$ (HP), 114.3 MW (IP) and 66.8 MW (LP). The pump consumes 3.15 MW. Based on the low heating value of the natural gas, the efficiency of the steam turbine is equal to $18.9 \%$.

Because of the complementary temperature ranges of the Brayton GT cycle $\left(1300^{\circ} \mathrm{C}-618^{\circ} \mathrm{C}\right)$ and the Rankine steam cycle $\left(618^{\circ} \mathrm{C}-67^{\circ} \mathrm{C}\right)$, natural gas combined cycle (NGCC) can produce significantly improved thermodynamic cycle efficiency (Figure 15).
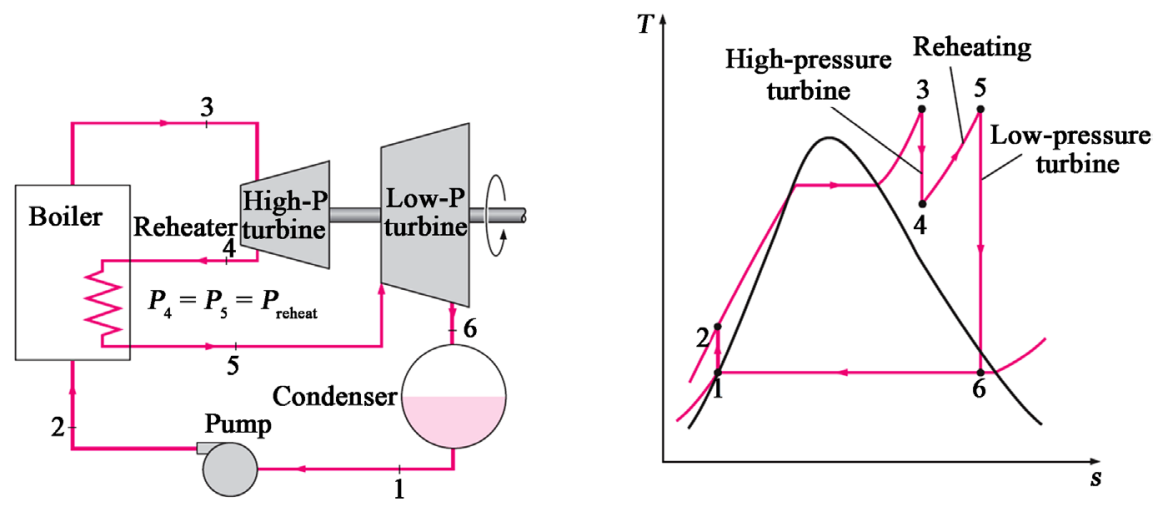

Figure 14. Ideal reheat rankine cycle [18].

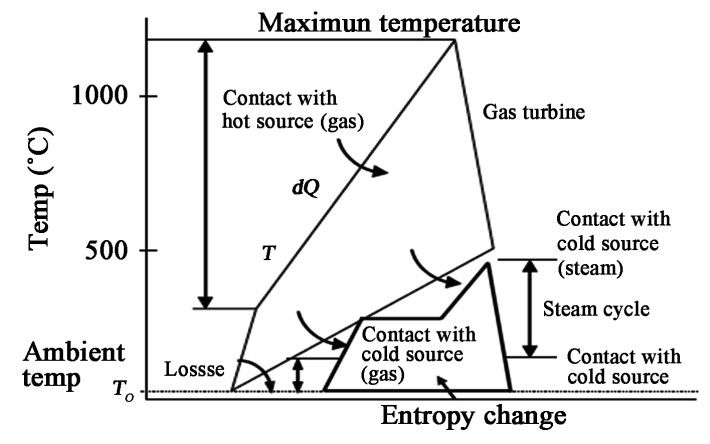

Figure 15. T-S diagram of NGCC cycle [19]. 
The net output of the NGCC power plant without flue gas recirculation and with a FGR ratio equal to 0.42 are respectively 610.89 and $618.57 \mathrm{MW}$. Based on the Low heating value (LHV) of the natural gas, the overall efficiency of the power plant increased by $1.1 \%$ from $57.5 \%$ from to $58.2 \%$.

\section{Summary of the Simulation Results}

First, the molar compositions of the flue gas without recirculation and with a circulation ratio of 0.42 are compared in Table 3. The molar composition of carbon dioxide and oxygen in the flue gas with a FGR ratio of 0.42 is close to the requirements of the composition of flue gas needed for an effective absorption of the $\mathrm{CO}_{2}\left(\mathrm{CO}_{2} \geq 10 \%\right.$ and $\left.\mathrm{O}_{2}<5 \%\right)$.

Secondly, the simulation results of the effects of the flue gas recirculation on the power input/output of the different equipment of the power plant are summarized in Table 4.

\section{Discussion and Conclusions}

The first goal of this work was to simulate a natural gas combined cycle (NGCC) power plant for a production of $620 \mathrm{MW}$ of electricity. The needed mass flow rates of natural gas and ambient air with $100 \%$ excess air were estimated by preliminary calculations assuming complete combustion of the natural gas. Since

Table 3. Molar composition of flue gas without recirculation and with a FGR ratio of 0.42 .

\begin{tabular}{ccc}
\hline Component & FGR $=0$ & FGR $=0.42$ \\
\hline $\mathrm{CO}_{2}$ & $\mathbf{0 . 0 5 0}$ & $\mathbf{0 . 0 9 2}$ \\
$\mathrm{O}_{2}$ & $\mathbf{0 . 1 0 9}$ & $\mathbf{0 . 0 3 5}$ \\
$\mathrm{H}_{2} \mathrm{O}$ & 0.067 & 0.067 \\
$\mathrm{~N}_{2}$ & 0.774 & 0.806 \\
Total & 1 & 1 \\
\hline
\end{tabular}

Table 4. Summary of simulation results.

\begin{tabular}{|c|c|c|c|c|c|c|}
\hline \multirow{2}{*}{ Equipment } & \multicolumn{2}{|c|}{ Power Input (MW) } & \multicolumn{2}{|c|}{ Power Output (MW) } & \multicolumn{2}{|c|}{ Net Output (MW) } \\
\hline & $\mathrm{FGR}=0$ & $\mathrm{FGR}=0.42$ & $\mathrm{FGR}=0$ & $\mathrm{FGR}=0.42$ & $\mathrm{FGR}=0$ & $\mathrm{FGR}=0.42$ \\
\hline Air Compressor & 299.73 & 174.8 & & & & \\
\hline FG compressor & 0 & 125.96 & & & & \\
\hline Gas turbine & & & 709.1 & 708.6 & & \\
\hline HP steam turbine & & & 22.85 & 32.74 & & \\
\hline IP steam turbine & & & 114.3 & 114.3 & & \\
\hline LP steam turbine & & & 67.47 & 66.79 & & \\
\hline Water pump & 3.1 & 3.1 & & & & \\
\hline Total & 302.83 & 303.86 & 913.72 & 922.43 & 610.89 & 618.57 \\
\hline
\end{tabular}


natural gas-fired power plants with Carbon Capture and Storage (CCS) are expected to play a significant role in order to reduce carbon dioxide emissions from the power generation sector, the effects of flue gas recirculation on the concentrations of $\mathrm{CO}_{2}$ and $\mathrm{O}_{2}$ in the flue gas leaving the simulated power plant were investigated. The objective was to reach a molar percentage of $\mathrm{CO}_{2}$ equal to $10 \%$. Moreover, in order to reduce technical problems due to amine oxidative degradation, the molar percentage of $\mathrm{O}_{2}$ in the flue gas should also be limited to $5 \%$. The recirculated flue gas is added to the secondary air to be utilized as the dilution air for cooling the turbine. In this investigation, the optimum value of 0.42 was obtained from the change of the slope of the molar concentration of oxygen in the flue gas versus the FGR ratio (Figure 5). Compared to the NGCC power plant without flue gas recirculation, the molar percentage of carbon dioxide in the flue gas increased from $5 \%$ to $9.2 \%$ and the molar percentage of oxygen decreased from $10.9 \%$ to $3.5 \%$.

The impacts of flue gas recirculation on the different energy inputs and outputs of the power plant were checked. As expected, it was observed that the flue gas recirculation ratio increases the energy needed for the compression of the recycled flue gas and decreases the energy consumption of the compressor of ambient air. The similarity between the two corresponding slopes (Figure 8) indicates that flue gas recirculation has no effects on the energy consumed by the compressors of the plant.

For the heat recovery steam generator (HRSG), the flue gas recirculation increased the heat available for the steam production by 3.1\% (Figure 9). These positive effects could be explained by the fact that flue gas has a specific mass heat capacity $\left(1.124 \mathrm{~kJ} / \mathrm{kg} \cdot{ }^{\circ} \mathrm{C}\right)$ higher than the specific mass heat capacity of air $\left(1.01 \mathrm{~kJ} / \mathrm{kg} .{ }^{\circ} \mathrm{C}\right)$. In concordance with the increase of the heat available in the HRSG, the simulation results indicated that the steam cycle produced $4.2 \%$ more power than the steam power plant with no flue gas recirculation. On the other hand, flue gas recirculation had no effects on the energy consumption of the water pump of the steam cycle.

The metallurgical limitation of the gas turbine was fixed at $1300^{\circ} \mathrm{C}$ in this investigation. The difference in the mass specific heat capacity between ambient air and flue gas was utilized to explain the cooling effects of the flue gas recirculation on the gas turbine. However, since the recirculated flue gas has a higher temperature $\left(222^{\circ} \mathrm{C}\right)$ than the compressed secondary air $\left(190^{\circ} \mathrm{C}\right)$, the cooling effects are very small and the gas turbine loses only $0.1 \%$ of its net power-output. The flue gas recirculation with a FGR ratio equal to 0.42 increased the net output of the power plant by $1.3 \%$ from 610.89 and $618.57 \mathrm{MW}$.

It can be conclude that: 1) the flue gas composition with a FGR ratio of 0.42 is suitable for an effective absorption of carbon dioxide by amine solutions and 2) based on the low heating value (LHV) of the natural gas, the overall efficiency of the power plant increased by $1.1 \%$ from $57.5 \%$ to $58.2 \% 3$ ) the positive effects of the flue gas recirculation on the heat available in the heat recovery steam generator (HRSG) and the resulting electricity produced by the steam turbine gene- 
rator(STG) are more important than the negative effects (cooling) of the recirculated flue gas on the power output of the combustion turbine generator (CTG).

\section{Acknowledgements}

The authors wish to thank the Higher Colleges of Technology of the UAE for supporting this research project.

\section{References}

[1] https://www.eia.gov/energyexplained/index.cfm?page=electricity_in_the_united_sta tes

[2] Bolland, O. and Sæther, S. (1992) New Concepts for Natural Gas Fired Power Plants Which Simplify the Recovery of Carbon Dioxide. Energy Conversion and Management, 33, 467-475. https://doi.org/10.1016/0196-8904(92)90045-X

[3] Asa, M., Simon, H. and Thore, B. (2006) Technical, Environmental and Economic Analysis of Co-Firing of Gasified Biofuel in a Natural Gas Combined Cycle (NGCC) Combined Heat and Power (CHP) Plant. Energy, 31, 1614-1631. https://doi.org/10.1016/j.energy.2005.05.029

[4] Al Wahedi, F.S. and Dadach, Z. (2013) Cost Effective Strategies to Reduce $\mathrm{CO}_{2}$ Emissions in the UAE: A Literature Review. Industrial Engineering \& Management Journal, 2, 1-9. https://doi.org/10.4172/2169-0316.1000116

[5] Akram, M., Khandelwal, B., Blakey, S. and Wilson, C.W. (2013) Preliminary Calculations on Post Combustion Carbon Capture from Gas Turbines with Flue Gas Recycle. Proceedings of ASME Turbo Expo 2013: Turbine Technical Conference and Exposition (GT2013), San Antonio, Texas, USA, 3-7 June 2013.

[6] Thong, D., Dave, N., Feron, P. and Merched, A. (2012) Environmental Impacts of Amine-Based $\mathrm{CO}_{2}$ Post Combustion Capture (PCC) Process. CSIRO-Advanced Coal Technology Portfolio.

[7] Chakravarti, S., Gupta, A. and Hunek, B. (2001) Advanced Technology for the Capture of Carbon Dioxide from Flue Gases. 1st National Conference on Carbon Sequestration, Washington DC, 15-17 May 2001, 1-10.

[8] Ibrahim, T.K. and Rahman, M.M. (2012) Effect of Compression Ratio on Performance of Combined Cycle Gas Turbine. International Journal of Energy Engineering, 2, 9-14.

[9] Mathieu, P. and Bolland, O. (2013) Comparison of Costs for Natural Gas Power Generation with $\mathrm{CO}_{2}$ Capture. Energy Procedia, 37, 2406-2419. https://doi.org/10.1016/j.egypro.2013.06.122

[10] Piper, J.E. (1999) Operations and Maintenance Manual for Energy Management, Library of Congress Catalogues, 93.

[11] Combustor in Wikipedia.

[12] Røkke, P.E. and Hustad, J.E. (2005) Exhaust Gas Recirculation in Gas Turbines for Reduction of $\mathrm{CO}_{2}$ Emissions; Combustion Testing with Focus on Stability and Emissions. International Journal of Thermodynamics, 8, 167-173.

[13] ElKady, A.M., et al. (2009) Application of Exhaust Gas Recirculation in a DLN F-Class.

[14] Abu Zahra, M.R.M. (2009) Carbon Dioxide Capture from Flue Gas. PhD Dissertation, Delft University of Technology, Netherlands. 
[15] Hiraoka, T. (2000) Reduction of Fuel Costs and $\mathrm{CO}_{2}$ Emissions by $\mathrm{O}_{2}$ Control for Packaged Boilers. Yokogawa Technical Report, 44, 85-86. (In Japanese)

[16] Ishikawa, M., Terauchi, M., Komori, T. and Yasuraoka, J. (2008) Development of High Efficiency Gas Turbine Combined Cycle Power Plant, Mitsubishi Heavy Industries, Ltd. Technical Review, 45.

[17] Allahyari, N. (2013) Economic Evaluation of Capturing $\mathrm{CO}_{2}$ from Natural Gas Power Plant and Injecting $\mathrm{CO}_{2}$ for Enhanced Oil Recovery as an Integrated System. Ms. Thesis, University of Regina, Canada.

[18] Rankine Cycle, Wikipedia.

[19] Beér, J.M. (2007) High Efficiency Electric Power Generation: The Environmental Role. Progress in Energy and Combustion Science, 33, 107-134.

https://doi.org/10.1016/j.pecs.2006.08.002 


\section{Nomenclature}

$\begin{array}{ll}\text { AFR } & \text { Air Fuel Ratio } \\ \text { C } & \text { Condenser } \\ \text { CC } & \text { Combustor } \\ \text { CCS } & \text { Carbon Capture \& Storage } \\ \text { CTG } & \text { Combustion Turbine Generator } \\ \text { EA } & \text { Excess Air (\%) } \\ \text { EAR } & \text { Excess Air Ratio } \\ \text { EOR } & \text { Enhanced Oil Recovery } \\ \text { FGR } & \text { Flue Gas Recirculation } \\ \text { HHV } & \text { High Heating Value (MJ/kg) } \\ \text { HP } & \text { High pressure (bars) } \\ \text { HRSG } & \text { Heat Recovery Heat Generator } \\ \text { IEA } & \text { International Energy Agency } \\ \text { IP } & \text { Intermediate Pressure (bars) } \\ \text { IPCC } & \text { Intergovernmental Panel on Climate Change } \\ \text { K } & \text { Compressor } \\ \text { LHV } & \text { Low Heating Value (MJ/Kg) } \\ \text { LP } & \text { Low pressure (bars) } \\ \text { NG } & \text { Natural Gas } \\ \text { NGCC } & \text { Natural Gas Combined Cycle } \\ \text { P } & \text { Pump } \\ \text { SRK } & \text { Soave Redlich-Kwong } \\ \text { STG } & \text { Steam Turbine Generator } \\ \text { Greek letters } & \\ \eta & \text { Energy efficiency (\%) } \\ \text { Subscripts } & \\ \text { Iso } & \text { Isentropic } \\ \text { Superscripts } & \\ \text { k } & \text { Specific heat ratio } \\ & \end{array}$

